\title{
PHENOLICS CONTENT IN BUCKWHEAT FLOUR
}

\author{
Ilze Beitāne", Gita Krūmiṇa-Zemture, Zanda Krūma, and Ingmārs Cinkmanis \\ Faculty of Food Technology, Latvia University of Life Sciences and Technologies, 22 Rīgas Str., LV-3004, Jelgava, LATVIA \\ \# Corresponding author, Ilze.Beitane@llu.lv
}

Communicated by Daina Kārkliṇa

\begin{abstract}
The objective of the current study was to analyse the total phenolic concentration (TPC), total flavonoid concentration (TFC), individual phenolic compound concentration and DPPH' radical scavenging activity of four buckwheat (raw, roasted, white and dark) flour samples obtained from the Latvian market, in comparison to those of wheat flour, which is the most common ingredient in production of cereal products. TPC, TFC, and DPPH' radical scavenging activity values were determined using spectrophotometric methods. Phenolic compounds were determined based on the high performance liquid chromatographic method (HPLC). All buckwheat flour samples had significantly higher TPC and TFC than wheat flour. The highest TPC (974.74 mg GAE.100 g $\left.\mathrm{g}^{-1} \mathrm{DW}\right)$ and TFC (495.31 mg CE.100 $\left.\mathrm{g}^{-1} \mathrm{DW}\right)$ was found in raw buckwheat flour $(\mathrm{p}<0.05)$. Buckwheat flour samples demonstrated similar DPPH' radical scavenging activity, which ranged from 21.067 to $22.644 \mathrm{mM} T E \cdot 100 \mathrm{~g}^{-1}$ dry matter, and was significantly higher $(p<0.05)$ than in wheat flour (0.731 mM TE.100 g $\mathrm{g}^{-1}$ of dry matter). Dark buckwheat flour contained the highest level of rutin $\left(4.613 \mathrm{mg} \cdot 100 \mathrm{~g}^{-1}\right)$, whereas raw buckwheat flour displayed the highest level of 3.5-dihydroxybenzoic acid $\left(6.356 \mathrm{mg} \cdot 100 \mathrm{~g} \mathrm{~g}^{-1}\right)$, sinapic acid $\left(0.947 \mathrm{mg}^{\left.-100 ~ \mathrm{~g}^{-1}\right)}\right.$ and epicatechin $\left(2.608 \mathrm{mg} \cdot 100 \mathrm{~g}^{-1}\right)$.
\end{abstract}

Key words: buckwheat, phenolic compounds, flavonoids, $D P P H^{\prime}$ radical scavenging activity.

\section{INTRODUCTION}

Buckwheat's potential contribution to sustainable agriculture and to nutritional and health benefits of humans should not be underestimated (Izydorczyk et al., 2014). Buckwheat has high levels of flavonoids and other bioactive compounds (Krkoskova and Mrazova, 2005) with a potential to inhibit lipoprotein oxidation and to reduce the risk of cardiovascular diseases (Jiang et al., 2007). Epidemiological studies of Hertog et al. (1995) and Chao et al. (2002) have suggested a protective role of flavonoids in buckwheat seeds helping to prevent coronary heart diseases and possibly cancers. The content and composition of flavonoids in common buckwheat (Fagopyrum esculentum) and tartary buckwheat (Fagopyrum tataricum) seeds vary widely. Li and Zhang (2001) reported that the total flavonoid content in common buckwheat was $10 \mathrm{mg} \cdot \mathrm{g}^{-1}$, whereas in tartary buckwheat it was $40 \mathrm{mg} \cdot \mathrm{g}^{-1}$. Buckwheat contains several flavonoids, like rutin, quercetin, kaempferol, orientin/isoorientin, and vitexin/isovitexin, which have demonstrated antioxidant, antimicrobial and anti-inflammatory properties (Cai et al., 2004). Compared to most grain crops, buckwheat contains more rutin, which is reported to be the most abundant flavonoid providing natural antioxidant, antiinflammatory and anti-carcinogenic properties, i.e. rutin may inhibit lipid peroxidation within food (Oomah and Mazza, 1996; Lin et al., 2009; Choy et al., 2013; Wron- kowska et al., 2015). Quercetin concentration in buckwheat is several times lower than that of rutin (Fabjan et al., 2003). Rutin and quercetin concentration changes depending on technological parameters applied in seeds processing (Bonafaccia et al., 2003). Holasova et al. (2002) pointed out that the antioxidant potential of buckwheat is determined mainly by phenolic compounds.

The objective of the current study was to analyse the total phenolic concentration (TPC), total flavonoid concentration (TFC), phenolic compound concentration and $\mathrm{DPPH}^{\prime}$ radical scavenging activity of four buckwheat (raw, roasted, white and dark) flour samples obtained from the Latvian market, in comparison to those of wheat flour, which is the most common ingredient in production of cereal products.

\section{MATERIALS AND METHODS}

The research was conducted using raw (Raw-BF), roasted (Roasted-BF), white (White-BF) and dark (Dark-BF) buckwheat flours obtained from the "Bebri" farmstead, Latvia. Fine wheat flour (WF) for control purposes was purchased from "Dobeles Dzirnavnieks", Latvia. Wheat flour was chosen as the control in this study due to its widespread and varied application in the food industry. Particle size of wheat and buckwheat flours was not bigger than $160 \mu \mathrm{m}$. 
The total phenolic concentration (TPC) of the buckwheat and wheat extracts was determined applying the Folin-Ciocalteu spectrophotometric method (Singleton et al., 1999) with some modifications. To $0.5 \mathrm{ml}$ of extract $2.5 \mathrm{ml} \mathrm{Fo-}$ lin-Ciocalteu reagent (diluted 10 times with water) was added and then, after 3 minutes, $2 \mathrm{ml}$ sodium carbonate $\left(\mathrm{Na}_{2} \mathrm{CO}_{3}\right)\left(75 \mathrm{~g} \cdot \mathrm{l}^{-1}\right)$ was added. The sample was mixed. The control sample contained all the reaction reagents except the extract. After $2 \mathrm{~h}$ of incubation at room temperature, the absorbance was measured at $765 \mathrm{~nm}$. Total phenol concentration was expressed as gallic acid equivalents (GAE) $100 \mathrm{~g}^{-1}$ dry weight (DW) of the buckwheat or wheat flour.

The total flavonoid concentration (TFC) was measured by a colorimetric method (Kim et al., 2003) with minor modification. The extraction solution used was the same as TPC. To $0.5 \mathrm{ml}$ of extract $2 \mathrm{ml}$ double distilled $\mathrm{H}_{2} \mathrm{O}$ was added and it was subsequently mixed with $0.15 \mathrm{ml} \mathrm{5 \%}$ sodium nitrite $\left(\mathrm{NaNO}_{2}\right)\left(50 \mathrm{~g} \cdot \mathrm{l}^{-1}\right)$. After $5 \mathrm{~min}, 0.15 \mathrm{ml} 10 \%$ aluminium chloride $\left(\mathrm{AlCl}_{3} \cdot 6 \mathrm{H}_{2} \mathrm{O}\right)$ solution was added. The mixture was allowed to stand for another $5 \mathrm{~min}$ and then 1 $\mathrm{ml} 1 \mathrm{M}$ sodium hydroxide $(\mathrm{NaOH})$ was added. The reaction solution was thoroughly mixed. After $15 \mathrm{~min}$ of incubation at room temperature, the absorbance was measured at $415 \mathrm{~nm}$. Total flavonoid concentration was expressed as catechin equivalents (CE) $100 \mathrm{~g}^{-1} \mathrm{DW}$ of the buckwheat or wheat flour.

HPLC method was used for the analysis of phenolic compounds. The analysis was performed with a Shimadzu HPLC system LC-20 Prominence including Photo-diode Array detector SPD-M20A, Solvent Delivery Unit LC20AD, Column Oven CTO-20A, Autosampler SIL-20A, System Controller CBM-20A and data system LC solution software (Fig. 1). Preparation of calibration solution was as follows: weighed in $100 \mathrm{ml}$ volumetric flask with narrow neck $6.8 \pm 0.1 \mathrm{mg}$ gallic acid, $7.4 \pm 0.1 \mathrm{mg}$ 3.5-dihydroxybenzoic acid, $11.4 \pm 0.1 \mathrm{mg}$ 3.4-dihydroxybenzoic acid, $12.0 \pm 0.1 \mathrm{mg}$ catechin, $12.8 \pm 0.1 \mathrm{mg}$ 4-hydroxybenzoic acid, $13.1 \pm 0.1 \mathrm{mg}$ chlorogenic acid, $12.1 \pm 0.1 \mathrm{mg}$ homovanillic acid, $14.5 \pm 0.1 \mathrm{mg}$ vanillic acid, $13.8 \pm 0.1$ $\mathrm{mg}$ caffeic acid, $16.0 \pm 0.1 \mathrm{mg}$ epicatechin, $18.8 \pm 0.1 \mathrm{mg}$ syringic acid, $9.8 \pm 0.1 \mathrm{mg}$ vanillin, $12.1 \pm 0.1 \mathrm{mg}$ coumaric acid, $88.1 \pm 0.1 \mathrm{mg}$ sinapinic acid, $9.2 \pm 0.1 \mathrm{mg}$ ferulic acid, $11.2 \pm 0.1 \mathrm{mg}$ 2-hydroxycinnamic acid, $6.1 \pm$
$0.1 \mathrm{mg}$ rutin, $10.3 \pm 0.1 \mathrm{mg}$ trans-4-hydroxycinnamic acid, $4.3 \pm 0.1 \mathrm{mg}$ quercetin, $9.1 \pm 0.1 \mathrm{mg}$ luteolin and $9.6 \pm 0.1$ mg kaempherol and filled with HPLC grade CHROMA$\mathrm{SOLV}^{\circledR}$ methanol till mark and mixed. Parameters of chromatography were as follows. An analytical column PerkinElmer C18, 4, $6 \mathrm{~mm} \times 250 \mathrm{~mm}, 5 \mu \mathrm{m}$ and temperature of column $+30{ }^{\circ} \mathrm{C}$ was used for separation of phenolic compounds at wavelength $278 \mathrm{~nm}$. Injection volume of samples was $100 \mu \mathrm{L}$. Mobile phase was A (deionized water), B (HPLC grade CHROMASOLV ${ }^{\circledR}$ methanol) and C (Acetic acid solution for HPLC) in the gradient conditions (Table 1). Start flow rate was $1.0 \mathrm{ml} \cdot \mathrm{min}^{-1}$.

Antioxidant activity of the buckwheat and wheat extracts was measured on the basis of the scavenging activities of the stable 2.2-diphenyl-1-picrylhydraziyl (DPPH') radical as outlined by $\mathrm{Yu}$ et al. (2003). The antioxidant reaction

Table 1

\section{GRADIENT CONDITIONS}

\begin{tabular}{|c|c|c|}
\hline \multirow[t]{2}{*}{ Time } & \multicolumn{2}{|c|}{ Mobile phase } \\
\hline & $\mathrm{B}$ & $\mathrm{C}$ \\
\hline Start & 0 & 2.5 \\
\hline $2 \mathrm{~min}$ & 15 & 2.4 \\
\hline $12 \mathrm{~min}$ & 18 & 2.2 \\
\hline $12 \mathrm{~min}$ & \multicolumn{2}{|c|}{ Flow rate $=0.8 \mathrm{~mL} \cdot \mathrm{min}^{-1}$} \\
\hline $20 \mathrm{~min}$ & 20 & 1.8 \\
\hline $20 \mathrm{~min}$ & \multicolumn{2}{|c|}{ Flow rate $=0.6 \mathrm{~mL} \cdot \mathrm{min}^{-1}$} \\
\hline $25 \mathrm{~min}$ & \multicolumn{2}{|c|}{ Flow rate $=0.5 \mathrm{~mL} \cdot \mathrm{min}^{-1}$} \\
\hline $30 \mathrm{~min}$ & 25 & 1.6 \\
\hline $35 \mathrm{~min}$ & \multicolumn{2}{|c|}{ Flow rate $=0.4 \mathrm{~mL} \cdot \mathrm{min}^{-1}$} \\
\hline $40 \mathrm{~min}$ & 30 & 1.4 \\
\hline $45 \mathrm{~min}$ & \multicolumn{2}{|c|}{ Flow rate $=0.8 \mathrm{~mL} \cdot \mathrm{min}^{-1}$} \\
\hline $50 \mathrm{~min}$ & 45 & 1 \\
\hline $50 \mathrm{~min}$ & \multicolumn{2}{|c|}{ Flow rate $=0.7 \mathrm{~mL} \cdot \mathrm{min}^{-1}$} \\
\hline $55 \mathrm{~min}$ & 55 & 0.9 \\
\hline $55 \mathrm{~min}$ & \multicolumn{2}{|c|}{ Flow rate $=0.8 \mathrm{~mL} \cdot \mathrm{min}^{-1}$} \\
\hline $65 \mathrm{~min}$ & 85 & 0.6 \\
\hline $65 \mathrm{~min}$ & \multicolumn{2}{|c|}{ Flow rate $=0.85 \mathrm{~mL} \cdot \mathrm{min}^{-1}$} \\
\hline $70 \mathrm{~min}$ & 100 & 0 \\
\hline $70 \mathrm{~min}$ & \multicolumn{2}{|c|}{ Flow rate $=1.0 \mathrm{~mL} \cdot \mathrm{min}^{-1}$} \\
\hline $73 \mathrm{~min}$ & 0 & 2.5 \\
\hline $78 \mathrm{~min}$ & STOP & STOP \\
\hline
\end{tabular}

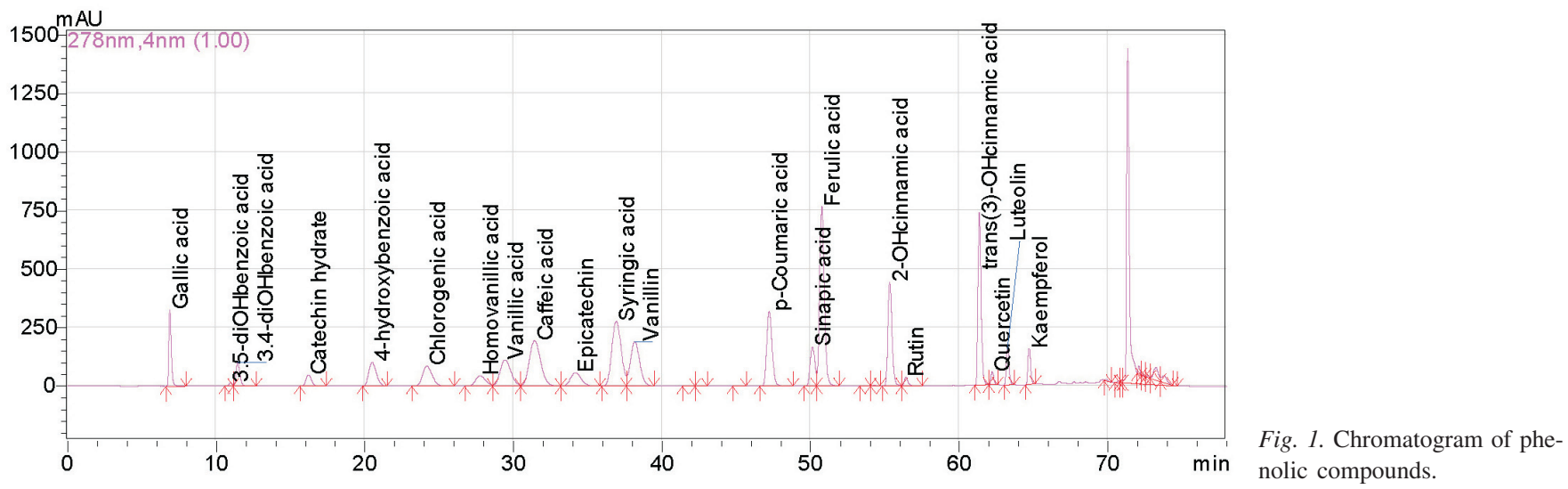


was initiated by transferring $0.5 \mathrm{ml}$ of buckwheat or wheat extract into a sample cavity containing $3.5 \mathrm{ml}$ of freshly prepared DPPH' methanol solution $\left(0.004 \mathrm{~g} \mathrm{DPPH}^{\prime}\right.$ to 100 $\mathrm{ml}$ methanol). After $30 \mathrm{~min}$ of incubation in the dark at room temperature, the absorbance was measured at $517 \mathrm{~nm}$. Lower absorbance of the reaction mixture indicates higher free radical scavenging activity (Zhao et al., 2008). The radical scavenging capacity (RSC) was expressed as Trolox $\mathrm{mM}$ equivalents (TE) $100 \mathrm{~g}^{-1} \mathrm{DW}$ of the buckwheat and wheat flour.

Moisture content of wheat and buckwheat flour samples was determined according to the methods of LVS EN ISO 712:2010 A.

\section{RESULTS}

The total phenolic and total flavonoid concentrations of wheat and buckwheat flour samples are shown in Figure 2. All buckwheat flour samples had significantly $(p<0.05)$ higher total phenolic and flavonoid concentration than in wheat flour. The highest total phenolic (974.74 mg GAE.100 g $\mathrm{g}^{-1}$ DW) and total flavonoid (495.31 mg $\left.\mathrm{CE} \cdot 100 \mathrm{~g}^{-1} \mathrm{DW}\right)$ concentration was observed in the Raw-BF sample. Acquired results of Raw-BF were two (for Roasted-BF) or three times (for White-BF and Dark-BF) higher in comparison with other buckwheat flour samples. This finding is in line with previous studies on the total phenolic concentration in raw and roasted buckwheat groats (Wronkowska et al., 2015). Similar total phenolic and total flavonoid concentration was observed for White-BF and Dark-BF, whereas Roasted-BF showed higher total phenolic and total flavonoid concentration. The results of Analysis of Variance among the studied buckwheat flour samples revealed significant $(p<0.05)$ differences regarding the total phenolic and total flavonoid concentration between Raw-BF and other buckwheat flour samples; and between RoastedBF and White- and Dark-BF.

The concentration of individual phenolic compounds in wheat and buckwheat flour samples is summarised in Table 2. There were nine phenolic compounds identified in wheat flour, fifteen - in Raw-BF, fourteen — in Roasted-BF, sixteen - in White-BF, and eighteen - in Dark-BF. Wheat flour contained the highest concentration of catechin hydrate, quercetin, luteolin and trans(3)-hydroxycinnamic acid. A markedly higher concentration of 3.5-dihydroxybenzoic acid, chlorogenic acid, vanillic acid, caffeic acid, epicatechin, p-Coumaric acid, sinapic acid, and 2-hydroxycinnamic acid was observed in Raw-BF. It was found that gallic acid and homovanillic acid concentration was higher in Roasted-BF, furthermore homovanillic acid was not present in other samples. White-BF contained the highest levels of 4-hydroxybenzoic acid, vanillin, and ferulic acid, whereas Dark-BF - 3.4-dihydroxybenzoic acid, rutin, and kaempferol. Rutin concentration, which plays a significant role in the antioxidant capacity of buckwheat seeds (Jiang et al., 2007), was several times higher in Dark-BF (4.613 $\mathrm{mg} \cdot 100 \mathrm{~g}^{-1}$ ) in comparison with other flour. This might be

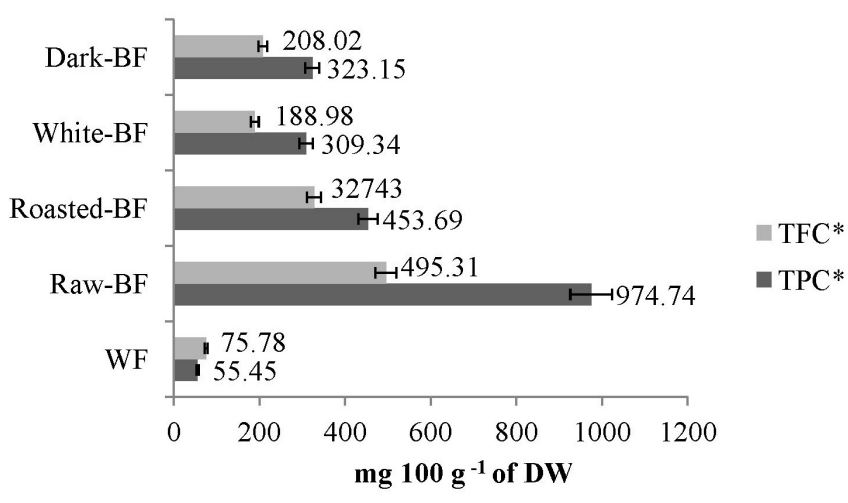

Fig. 2. The total phenolic and total flavonoid concentration of wheat (W) and buckwheat flour (BF) samples. TPC* (total phenolic concentration) was expressed as gallic acid equivalents (GAE) $100 \mathrm{~g}^{-1}$ dry weight (DW); $\mathrm{TFC}^{*}$ (total flavonoid concentration) was expressed as catechin equivalents (CE). $100 \mathrm{~g}^{-1} \mathrm{DW}$.

Table 2

CONCENTRATION OF PHENOLIC COMPOUNDS IN WHEAT (W) AND BUCKWHEAT FLOUR (BF) SAMPLES, $\mathrm{mg} \cdot 100 \mathrm{~g}^{-1}$

\begin{tabular}{|c|c|c|c|c|c|}
\hline Phenolic compounds & WF & $\begin{array}{c}\text { Raw- } \\
\text { BF }\end{array}$ & $\begin{array}{c}\text { Roasted- } \\
\text { BF }\end{array}$ & $\begin{array}{c}\text { White- } \\
\text { BF }\end{array}$ & $\begin{array}{c}\text { Dark- } \\
\text { BF }\end{array}$ \\
\hline Gallic acid & 0 & 0.011 & 0.015 & 0.003 & 0.006 \\
\hline 3.5-diOHbenzoic acid & 0 & 6.356 & 2.016 & 1.470 & 2.901 \\
\hline 3.4-diOHbenzoic acid & 0 & 0 & 0 & 0.038 & 0.204 \\
\hline Catechin hydrate & 3.014 & 0.641 & 0.145 & 0.340 & 0.268 \\
\hline 4-hydroxybenzoic acid & 0 & 0 & 0 & 0.018 & 0.015 \\
\hline Chlorogenic acid & 0 & 0.064 & 0 & 0.051 & 0.020 \\
\hline Homovanillic acid & 0 & 0 & 0.041 & 0 & 0 \\
\hline Vanillic acid & 0 & 0.239 & 0 & 0.008 & 0.151 \\
\hline Caffeic acid & 0 & 0.172 & 0.082 & 0.071 & 0.085 \\
\hline Epicatechin & 0 & 2.608 & 0 & 0.428 & 0.603 \\
\hline Syringic acid & 0 & 0 & 0 & 0 & 0 \\
\hline Vanillin & 0.012 & 0.021 & 0.006 & 0.039 & 0.035 \\
\hline p-Coumaric acid & 0 & 0.446 & 0.093 & 0.233 & 0.284 \\
\hline Sinapic acid & 0.274 & 0.947 & 0.090 & 0 & 0.014 \\
\hline Ferulic acid & 0.038 & 0.027 & 0.003 & 0.045 & 0.043 \\
\hline 2-OHcinnamic acid & 0.016 & 0.903 & 0.148 & 0.709 & 0.774 \\
\hline Rutin & 0.238 & 0.852 & 0.321 & 0.480 & 4.613 \\
\hline $\begin{array}{l}\operatorname{trans}(3)-O H c i n n a m i c \\
\text { acid }\end{array}$ & 0.210 & 0 & 0 & 0 & 0 \\
\hline Quercetin & 0.230 & 0.017 & 0.017 & 0.002 & 0.104 \\
\hline Luteolin & 0.072 & 0.012 & 0.005 & 0.005 & 0.034 \\
\hline Kaempferol & 0 & 0 & 0.002 & 0 & 0.293 \\
\hline
\end{tabular}

explained by the presence of husks in Dark-BF, as buckwheat husks have been noted to have the highest total phenolic concentration and antioxidant activity (Kerienè et al., 2015).

Literature reports that antioxidant activity correlates significantly with the total phenolic concentration (Kerienè et al., 2015). Similar tendencies were observed in this study, where Raw-BF had the highest total phenolic concentration and the highest $\mathrm{DPPH}^{\prime}$ radical scavenging activity (27.17 $\mathrm{mM}$ TE. $100 \mathrm{~g}^{-1} \mathrm{DM}$ ) among the flour samples. DPPH' radical scavenging activity of wheat and buckwheat flour sam- 


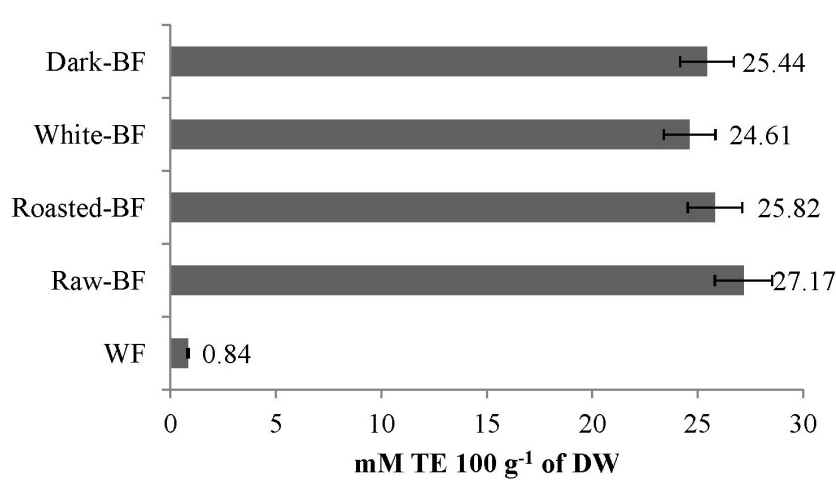

Fig. 3. DPPH' radical scavenging activity of wheat (W) and buckwheat flour (BF) samples. DW, dry weight.

ples is presented in Figure 3. Buckwheat flour samples had a significantly $(p<0.05)$ higher $\mathrm{DPPH}^{\prime}$ radical scavenging activity than wheat flour, which is confirmed by literature data (Djordjevic et al., 2011). No significant $(p>0.05)$ differences were detected among the buckwheat flour samples, where $\mathrm{DPPH}^{\prime}$ radical scavenging activity ranged from $24.61 \mathrm{mM}$ TE.100 $\mathrm{g}^{-1} \mathrm{DM}$ for White-BF to $27.17 \mathrm{mM}$ TE.100 $\mathrm{g}^{-1}$ DM for Raw-BF. The results showed that $\mathrm{DPPH}^{\prime}$ radical scavenging activity was not significant affected by the technological processes applied in seed processing (roasted buckwheat or raw) and the used raw material (buckwheat with husks or without). There is a need for further research.

\section{DISCUSSION}

The results of the current study confirm that buckwheat is an important source of bioactive substances, like phenols, flavonoids, and also has strong antioxidant activity. Djordjevic et al. (2011) indicated that buckwheat had the highest total phenolic concentration, with the highest $\mathrm{DPPH}^{\prime}$ radical scavenging activity among the four examined cereals. Similar conclusions were reported by Sedej et al. (2010), who reported that in buckwheat flour the concentration of phenolics and antioxidant activity were several times higher than those in winter wheat flour. However, the total phenolic concentration, total flavonoid concentration, concentration of phenolic compounds and $\mathrm{DPPH}^{\prime}$ radical scavenging activity of buckwheat was influenced the technological processes applied in seed processing (roasted buckwheat or raw) and the used raw material (buckwheat with husks or without). Roasting affects the functional properties and chemical composition of buckwheat groats: the reduction of parent antioxidants and the formation of Maillard reaction products (Wronkowska et al., 2015; Zielińska et al., 2007). Wronkowska et al. (2015) showed that raw buckwheat groats were almost two times richer in total phenolic and phenolic compounds than roasted groats. Similar conclusions were obtained in the current research. Roasted-BF had $62 \%$ lower rutin concentration than in Raw-BF which could be explained by the hydro-thermal processes used for roasting. However, the highest $(p<0.05)$ concentration of rutin was found in Dark-BF due to the presence of husks. This confirms the results of Li et al. (2013). Literature indicates that there is a positive correlation between the rutin and total phenolic concentration of buckwheat grain with husks (Kerienè et al., 2015). The current study did not confirm this, as Dark-BF had the highest rutin concentration, whereas Raw-BF had the highest total phenolic concentration among the buckwheat flour samples. Raw-BF contained significantly $(p<0.05)$ high amount of sinapic acid $\left(0.947 \mathrm{mg} \cdot 100 \mathrm{~g}^{-1}\right)$ among the buckwheat flour samples. Roy and Prince (2012) indicated that sinapic acid had a preventive effect against myocardial infarct, also a neuro-protective and anti-inflammatory effect.

Buckwheat is recognised as a good source of flavonoids with a potential to inhibit lipoprotein oxidation and to reduce the risk of cardiovascular diseases (Izydorczyk et al., 2014; Jiang et al., 2007). However, the current research data showed significant differences in the total flavonoid content across the buckwheat flour samples. Izydorczyk et al. (2014) indicated that the groats of tartary buckwheat contained a 40-60 times higher concentration of total flavonoids than the other buckwheat species. Similar conclusions were reported by Uddin et al. (2013), who found that the flavonoid concentration depended on the cultivar. The current study showed that the total flavonoid concentration was affected by the technological processes applied in seed processing and the used raw material.

The highest $\mathrm{DPPH}^{\prime}$ radical scavenging activity was observed in Raw-BF which confirmed previous observations (Hęś et al., 2014). Guo et al. (2011) suggested that tartary buckwheat may serve as an excellent dietary source of free radical scavengers.

\section{CONCLUSIONS}

Buckwheat flours are products that are rich in bioactive substances, the concentration of which is affected by the used raw material (buckwheat with husks or without) and the technological processes applied in seed processing (roasted buckwheat or raw). Raw-BF showed the highest total phenolic and total flavonoid concentration as well the highest DPPH' radical scavenging activity. Raw-BF had a high potential as a raw material for functional food development. Due to the high level of rutin, Dark-BF can be used as a functional food.

\section{ACKNOWLEDGEMENTS}

The study was supported by the State Research Programme "Agricultural Resources for Sustainable Production of Qualitative and Healthy Foods in Latvia" (AgroBioRes) (2014 2017), project No. 4 "Sustainable use of local agricultural resources for qualitative and healthy food product development" (FOOD) and the project "Strengthening Research Capacity in the Latvia University of Agriculture". 


\section{REFERENCES}

Bonafaccia, G., Marocchini, M., Kreft, I. (2003). Composition and technological properties of the flour and bran from common and tartary buckwheat. Food Chem., 80, 9-15.

Cai, Y. Z., Corke, H., Li, W. D. (2004). Buckwheat. In: Wrigley, C. W., Corke, H., Walker, C. E. (eds.). Encyclopedia of Grain Science. Vol. 1. Elsevier Academic Press, Oxford, pp. 120-128.

Chao, P. L., Hsiu, S., Hou, Y. (2002). Flavonoids in herbs: Biological fates and potential interactions with xenobiotics. J. Food Drug Anal., 10, $219-228$

Choy, A. L., Morrison, P. D., Hughes, J. G., Marriott, P. J., Small, D. M. (2013). Quality and antioxidant properties of instant noodles enhanced with common buckwheat flour. J. Cereal Sci., 57, 281-287.

Djordjevic, T., Šiler-Marinkovic, S. S., Dimitrijevic-Brankovic, S. I. (2011). Antioxidant activity and total phenolic content in some cereals and legumes. Int. J. Food Prop., 14, 175-184.

Fabjan, N., Rode, J., Košir, I. J., Wang, Z., Zhang, Z., Kreft, I. (2003). Tartary buckwheat (Fagopyrum tataricum Gaertn.) as a source of dietary rutin and quercitrin. J. Agr. Food Chem., 51, 6452-6455.

Guo, X. D., Ma, Y. L., Parry, J., Gao, J. M., Yu, L. L., Wang, M. (2011). Phenolics content and antioxidant activity of tartary buckwheat from different locations. Molecules, 16, 9850-9867.

Hertog, M. G. L., Kromhout, D., Aravanis, C., Blackburn, H., Buzina, R., Fidanza, F., Giampaoli, S., Jansen, A., Menotti, A., Nedeljkovic, S., Pekkarinen, M., Simic, B. S., Toshima, H., Feskens, E. J. M., Hollman, P. C. H., Katan, M. B. (1995). Flavonoid intake and long-term risk of coronary heart disease and cancer in seven countries study. Arch. Intern. Med., 155 (4), 381-386.

Hęś, M., Dziedzic, K., Górecka, D., Drożdżyńska, A., Gujska, E. (2014). Effect of boiling in water of barley and buckwheat groats on the antioxidant properties and dietary fiber composition. Plant. Food Hum. Nutr., 69, 276-282.

Holasova, M., Fiedlerova, V., Smrcinova, H., Orsak, M., Lachman, J., Vavreinova, S. (2002). Buckwheat - the source of antioxidant activity in functional foods. Food Res. Inter., 35, 207-211.

Izydorczyk, M. S., McMillan, T., Bazin, S., Kletke, J., Dushnicky, L., Dexter, J. (2014). Canadian buckwheat: A unique, useful and under-utilized crop. Can. J. Plant Sci., 94, 509-524.

Jiang, P., Burczynski, F., Campbell, C., Pierce, G., Austria, J. A., Briggs, C. J. (2007). Rutin and flavonoid contents in three buckwheat species Fagopyrum esculentum, $F$. tataricum, and $F$. homotropicum and their protective effects against lipid peroxidation. Food Res. Int., 40, 356-364.
Kerienè, I., Mankevičienè, A., Bliznikas, S., Jablonskytė-Raščè, D., Maikštėnienè, S., Česnulevičienè, R. (2015). Biologically active phenolic compounds in buckwheat, oats and winter spelt wheat. Zemdirbyste-Agriculture, 102 (3), 289-296.

Krkoskova, B., Mrazova, Z. (2005). Prophylatic components of buckwheat. Food Res. Int., 38, 561-568.

Li, F. H., Ya, Y. U. A. N., Yang, X. L., Tao, S. Y., Jian, M. I. N. G. (2013). Phenolic profiles and antioxidant activity of buckwheat (Fagopyrum esculentum Mõench and Fagopyrum tartaricum L. Gaerth) husks, brans, and fluors. J. Integr. Agr., 12, 1684-1693.

Li, S., Zhang, Q. H. (2001). Advances in the development of functional foods from buckwheat. Crit. Rev. Food Sci. Nutr., 41, 451-464.

Lin, L. Y., Liu, H. M., Yu, Y. W., Lin, S. D., Mau, J. L. (2009). Quality and antioxidant property of buckwheat enhanced wheat bread. Food Chem., 112, 987-991

Oomah, B. D., Mazza, G. (1996). Flavonoids and antioxidative activities in buckwheat. J. Agr. Food Chem., 44, 1746-1750.

Roy, S. J., Prince, P. S.M. (2012). Protective effects of sinapic acid on lysosomal dysfunction in isoproterenol induced myocardial infarcted rats. Food Chem. Toxicol., 50, 3984-3989.

Sedej, I. J., Sakač, M. B., Mišan, A. I. (2010). Antioxidant activity of wheat and buckwheat fluors. Matica Srpska J. Nat. Sci., 118, 59-68.

Singleton, V. L., Orthofer, R., Lamuela-Raventos, R. M. (1999). Analysis of total phenols and other oxidation substrates and antioxidants by means of Folin-Ciocalteu reagent. Method Enzymol., 29, 152-178.

Uddin, R., Li, X., Park, W. T., Kim, Y. B., Kim, S. J., Kim, Y. S., Lee, Y., Park, C.H., Park, S. U. (2013). Phenolic compound content in different organs of Korean common buckwheat cultivars. Asian J. Chem., 25, 424-426.

Wronkowska, M., Honke, J., Piskuła, M. K. (2015). Effect of solid-state fermentation with Rhizopus oligosporus on bioactive compounds and antioxidant capacity of raw and roasted buckwheat groats. Ital. J. Food Sci., 27, $424-431$.

Yu, L., Haley, S., Perret, J., Harris, M., Wilson, J., Haley, S. (2003). Antioxidant properties of bran extracts from Akron wheat grown at different locations. J. Agr. Food Chem., 51, 1566-1570.

Zhao, H., Fan, W., Dong, J., Lu, J., Chen, J., Shan, L., Lin, Y., Kong, W. (2008). Evaluation of antioxidant activities and total phenolic contents of typical malting barley varieties. Food Chem., 107, 296-304.

Zielińska, D., Szawara-Nowak, D., Michalska, A. (2007). Antioxidant capacity of thermally-treated buckwheat. Pol. J. Food Nutr. Sci., 57, $465-470$.

Received 7 November 2016

Accepted in the final form 8 November 2017

\section{FENOLU SATURS GRIKUU MILTOS}

Griki ir pseido graudaugs ar augstu uzturvērtību un ir būtisks biologíiski aktīvu vielu avots cilvēku uzturā. Tomēr kopējo fenolu, kopējo flavonoīdu un fenolu savienojumu saturu, kā arī antiradikālo aktivitāti griku miltos būtiski ietekmē sēklas apstrādes tehnoloğiskais process (vai sēklas tiek tikai attīintas un kaltētas, iegūstot zaḷos griķus, vai papildus tiek veikta termiskā apstrāde — grauzdēšana vai tvaicēšana pirms kaltēšanas, tādējādi iegūstot grauzdētos vai kaltētos griḳus) un izmantotās sēklu sastāvdaḷas (ar vai bez sēnalām). Pētījuma rezultāti parādīja, ka visos griḳu miltos (zaḷajos, grauzdētajos, baltajos un tumšajos) ir būtiski augstāks kopējo fenolu un kopējo flavonoīdu saturs, kā arī DPPH' antiradikālā aktivitāte, salīdzinot ar kviešu miltiem. Savukārt būtiski augstākais kopējo fenolu (974,74 mg GAE·100 g ${ }^{-1}$ sausnas) un kopējo flavonoīdu $\left(495,31 \mathrm{mg} \mathrm{CE} \cdot 100 \mathrm{~g}^{-1}\right.$ sausnas) saturs starp griḳu miltu paraugiem tika konstatēts zaliajiem grikiem. Rutīna saturs, kuram ir būtiska nozīme griķu antiradikālajā aktivitātē, būtiski variē starp griķu miltu paraugiem. Visaugtākais rutīna saturs tika noteikts tumšajos griķu miltos $\left(4,613 \mathrm{mg} \cdot 100 \mathrm{~g}^{-1}\right)$, salīdzinot ar baltajiem $\left(0,480 \mathrm{mg} \cdot 100 \mathrm{~g}^{-1}\right)$, zaliajiem $\left(0,852 \mathrm{mg} \cdot 100 \mathrm{~g}^{-1}\right)$ un grauzdētajiem $(0,321$ $\mathrm{mg} \cdot 100 \mathrm{~g}^{-1}$ ) griḳu miltiem, ko varētu skaidrot ar sēnalu klātbūtni tumšajos griḳu miltos. Izvērtējot DPPH' antiradikālo aktivitāti, visi griḳu miltu paraugi uzrādīja būtiski augstāku aktivitāti, salīdzinot ar kviešu miltiem. Tomēr starp pašiem griku miltu paraugiem būtiskas

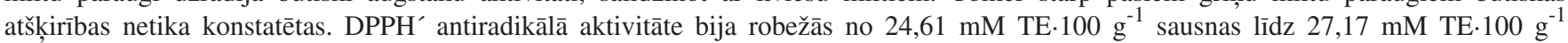
sausnas. Pētỉjuma dati apstiprina, ka griḳu milti ir nozīmīgs fenolu, flavonoīdu un polifenolu avots uzturā un tie varētu tikt izmantoti funkcionālu pārtikas produktu izstrādē. 